\title{
Treatment and outcome of aquaporin-4 antibody-positive NMOSD
}

\author{
A multinational pediatric study
}

Renata Barbosa Paolilo, MD,* Yael Hacohen, MD, PhD,* Elise Yazbeck, MD, Thais Armangue, MD, PhD, Arlette Bruijstens, MD, Christian Lechner, MD, Samira Luisa Apostolos-Pereira, MD, PhD,

Yana Martynenko, MD, Markus Breu, MD, Carolina de Medeiros Rimkus, MD, PhD, Evangeline Wassmer, MD, Matthias Baumann, MD, Laura Papetti, PhD, Marco Capobianco, MD, Barbara Kornek, MD, PhD, Kevin Rostásy, MD, José Albino da Paz, MD, PhD, Olga Ciccarelli, MD, PhD, Ming Lim, MD, PhD, Albert Saiz, MD, PhD, Rinze Neuteboom, MD, PhD, Romain Marignier, MD, PhD, Cheryl Hemingway, MD, PhD, Douglas Kazutoshi Sato, MD, PhD, and Kumaran Deiva, MD, PhD

Neurol Neuroimmunol Neuroinflamm 2020;7:e837. doi:10.1212/NXI.0000000000000837

\section{Abstract}

\section{Objective}

To describe the clinical phenotypes, treatment response, and outcome of children with antibodies against aquaporin-4 (AQP4-Ab) neuromyelitis optica spectrum disorder (NMOSD).

\section{Methods}

Retrospective, multicenter, and multinational study of patients with AQP4-Ab NMOSD aged $<18$ years at disease onset from a center in Brazil and 13 European centers. Data on demographics, clinical findings, and laboratory results were analyzed; calculation of annualized relapse rates (ARRs) pre- and on-treatment with disease-modifying therapies (DMTs) and of ORs for predictors of poor outcome was performed.

\section{Results}

A total of 67 children were identified. At last follow-up (median 4 years, interquartile range 2-10 years), 37/67(57.8\%) were found to have permanent disability. A more severe disease course was seen in the non-White ethnicity with both a shorter time to first relapse $(p=0.049)$ and a worse Expanded Disability Status Scale score at last follow-up $(p=0.008)$. The median ARR on treatment was 0.18 on azathioprine $(n=39$, range $0-4), 0$ on mycophenolate mofetil $(\mathrm{n}=18$, range $0-3)$, and 0 on rituximab $(\mathrm{n}=29$, range $0-2)$. No patient treated with rituximab as first-line therapy relapsed. Optic neuritis at onset was associated with a poor visual outcome below 20/200 (OR 8.669, 95\% CI 1.764-42.616, $p=0.008$ ), and a younger age at onset was associated with cognitive impairment (OR 0.786, 95\% CI 0.644-0.959, $p=0.018$ ).

\author{
Correspondence \\ Dr. Paolilo \\ renatabpaolilo@gmail.com
}

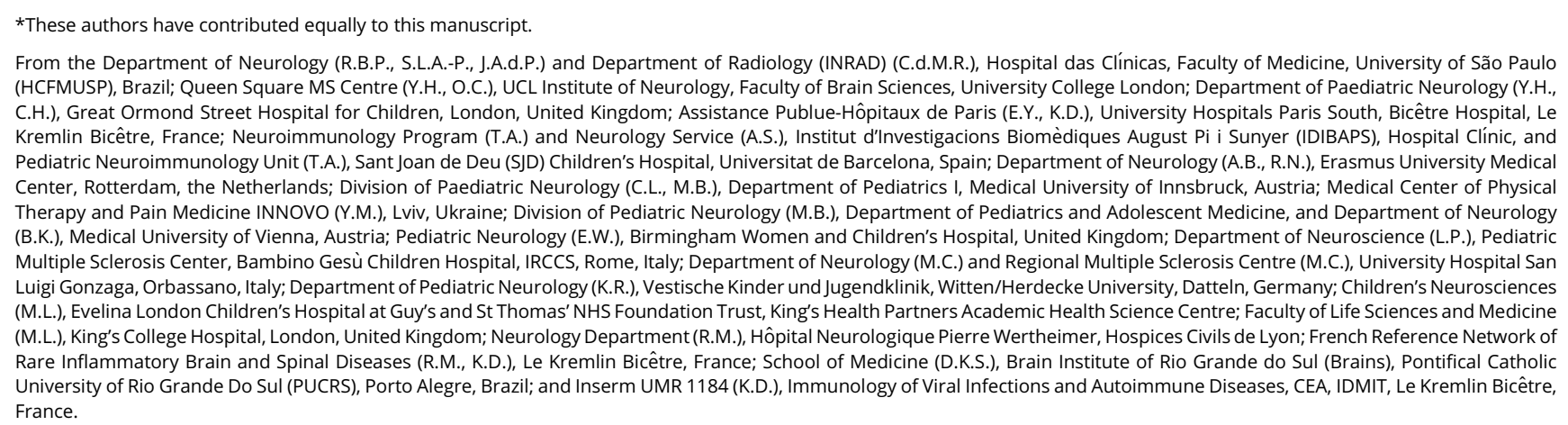

Go to Neurology.org/NN for full disclosures. Funding information is provided the end of the article.

The Article Processing Charge was funded by Assistance Publique-Hôpitaux de Paris, Hôpitaux Universitaires Paris Saclay.

This is an open access article distributed under the terms of the Creative Commons Attribution-NonCommercial-NoDerivatives License 4.0 (CC BY-NC-ND), which permits downloading and sharing the work provided it is properly cited. The work cannot be changed in any way or used commercially without permission from the journal. 


\section{Glossary}

ADS = acquired demyelinating syndrome; AQP4-Ab = antibodies against aquaporin-4; $\mathbf{A R R}=$ annualized relapse rate; $\mathbf{A Z A}=$ azathioprine; $\mathbf{C R F}=$ case reporting form; $\mathbf{D M T}=$ disease-modifying therapy; $\mathbf{E D S S}=$ Expanded Disability Status Scale; $\mathbf{I Q R}=$ interquartile range; $\mathbf{M M F}=$ mycophenolate mofetil; MOG-Ab = myelin oligodendrocyte glycoprotein antibody; NMOSD = neuromyelitis optica spectrum disorder; $\mathbf{O N}=$ optic neuritis; $\mathbf{T M}=$ transverse myelitis.

\section{Conclusions}

AQP4-Ab NMOSD in children is an aggressive disease with permanent disabilities observed in over half the cohort. All DMTs were associated with a reduction of ARR. First-line rituximab prevented further clinical relapses. International consensus on treatment protocols for children is required to reduce heterogeneity of treatment regimens used worldwide.

\section{Classification of evidence}

This study provides Class IV evidence that for children with AQP4-Ab NMOSD, all DMTs, particularly first-line rituximab, reduced the ARR and prevented further clinical relapses.

\section{Future Prospects for Children With Aquaporin-4 Antibody-Positive Neuromyelitis Optica Spectrum Disorder}

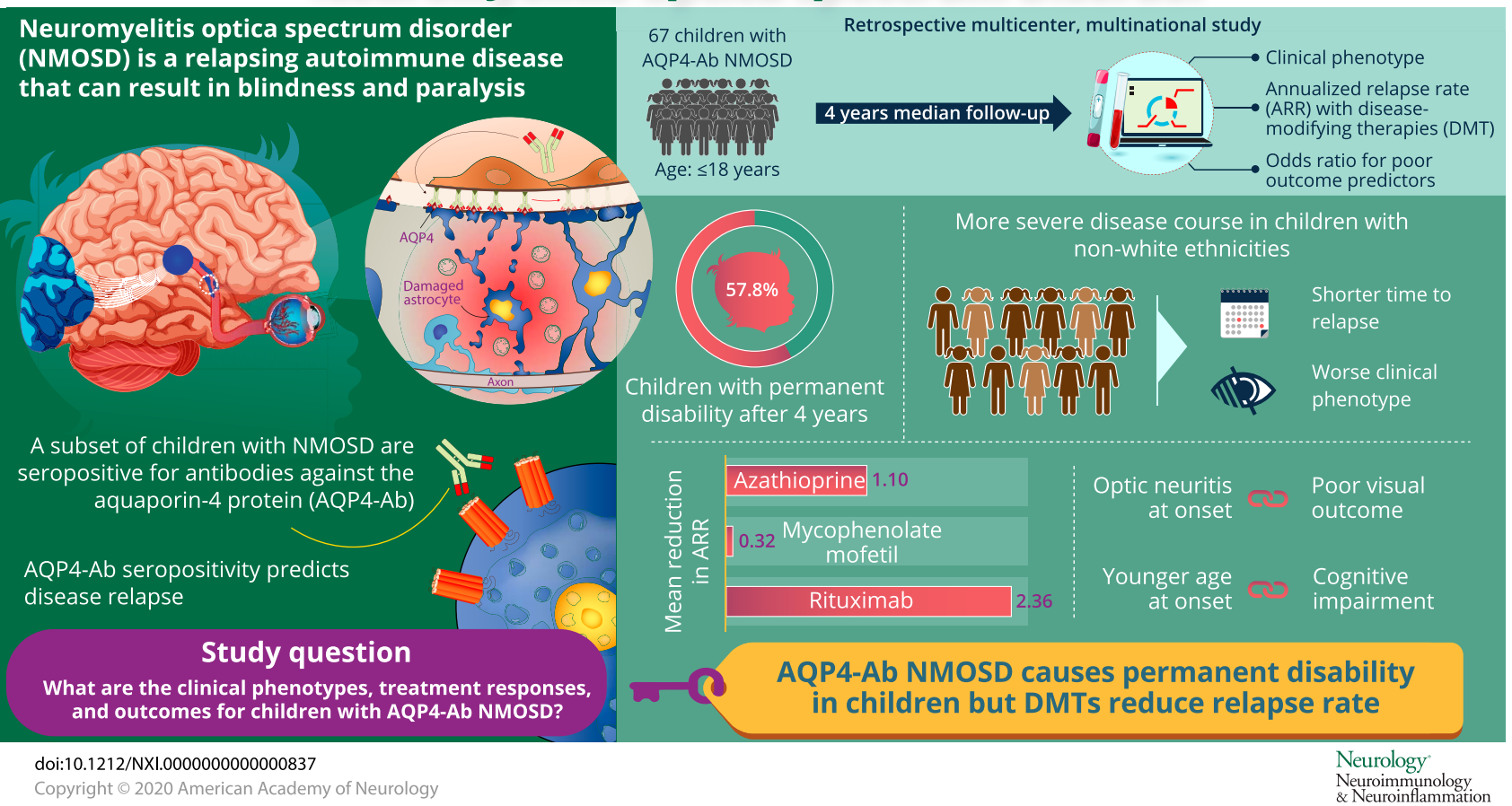

Antibodies against aquaporin-4 (AQP4-Ab) were first described in 2004 in patients with neuromyelitis optica $(\mathrm{NMO})^{1}$ allowing the expansion of the phenotype. ${ }^{2}$ The most recent criteria for the diagnosis of NMO spectrum disorder (NMOSD) stratify patients by the presence/absence of AQP4-Ab. ${ }^{3} \mathrm{AQP} 4-\mathrm{Ab}$ seropositivity is associated with relapsing disease. ${ }^{4,5}$ This led to the use of B-cell targeting therapies, which clearly reduce relapse rates. ${ }^{6}$ This reduction is not seen when therapies known to be effective for $\mathrm{MS}^{7}$ are used in NMOSD.

The clinical features and MRI abnormalities in children with AQP4-Ab NMOSD are similar to the adult phenotype. ${ }^{8-11}$ The prevalence of AQP4-Ab was reported in $0.7 \%(2 / 279)^{12}$ to $4.5 \%(3 / 64)^{13}$ of children presenting with a first presentation of acquired demyelinating syndrome (ADS) and 8/ $102(7.8 \%)$ of children with relapsing syndromes. ${ }^{14}$ Children are reported to have a less severe disease course and may take longer to reach disability than adults. ${ }^{15}$ Children are at a higher risk of visual impairment compared with adults but are less likely to acquire motor deficits. ${ }^{16}$ Previous pediatric publications highlighted that AQP4-Ab NMOSD in Europe is rare, ${ }^{9}$ whereas the prevalence in South America ${ }^{8}$ is higher.

With the rarity of pediatric presentation, treatment is derived from adult guidelines and can be influenced by medication availability and cost. Current available treatments used, such as azathioprine 
(AZA), mycophenolate mofetil (MMF), and rituximab, have not received regulatory approval for NMOSD. In this retrospective, multicenter, and multinational study, patients' demographics, first attack features, paraclinical characteristics, and disease course are described to ultimately evaluate responses to different treatment strategies in children with AQP4-Ab NMOSD.

\section{Methods}

\section{Participants}

In this multicenter, multinational study, we collected demographic, clinical, and radiologic data of 67 patients from a single center in Brazil (São Paulo, $\mathrm{n}=20$ ) and from 13 centers in 7 countries as part of the EU Paediatric Demyelinating Disease Consortium (United Kingdom $[\mathrm{n}=18]$, France $[\mathrm{n}=$ 11], Spain $[\mathrm{n}=6]$, Germany/Austria $[\mathrm{n}=5]$, the Netherlands/Belgium $[\mathrm{n}=4]$, Italy $[\mathrm{n}=2]$, and Ukraine $[\mathrm{n}=$ 1]). This consortium was initiated to study children with ADS, as part of the European Reference Network for Rare Immunodeficiency, Autoinflammatory and Autoimmune Disease.

We retrospectively identified participants who were recruited into the respective centers or national demyelination programs and fulfilled the following inclusion criteria: (1) NMOSD, fulfilling the 2015 International Panel for NMO diagnosis criteria, ${ }^{3}$ (2) AQP4-Abs detected at onset or at the time of a clinical relapse, using live cell-based assays in the local laboratories, and (3) age $<18$ years at first presentation.

\section{Standard protocol approvals, registrations, and patient consents}

Patients included in this study had been enrolled in national programs with respective review board/ethical committee approvals (Brazil [Hospital das Clínicas, Faculty of Medicine, University of São Paulo, São Paulo], France [Hôpital Bicêtre, Paris], the Netherlands [Medisch Ethische Toetsingscommissie Erasmus Medical Centre, Rotterdam], United Kingdom [West Midlands-South Birmingham Research Ethics Committee], Germany and Austria [University of Innsbruck Ethics Committee], and Spain [Hospital Clinic and by Sant Joan de Déu Children's Hospital] or provided verbal and/or written informed consent to the respective referring physician (Italy, Ukraine). All data were deidentified.

\section{Procedure}

Clinical data already collected as part of national demyelination programs were deidentified and entered by each participating investigator onto a unified case reporting form (CRF), detailing selected demographics, clinical findings and laboratory results (AQP4-Abs, CSF cell count, protein, and oligoclonal bands), first and subsequent attack characteristics, and treatment information. Demyelinating phenotype at onset and relapses were clinically determined according to established criteria ${ }^{18}$ as being optic neuritis ( $\left.\mathrm{ON}\right)$, transverse myelitis (TM), brainstem and/or cerebellar and/or hemispheric syndromes (associated with encephalopathy or without encephalopathy).

Brain and spinal cord MRI were performed in 61 and 50 patients, respectively, at disease onset. All patients had undergone brain and spinal cord imaging according to local MRI protocols (not routinely including orbits). Gadoliniumenhanced imaging was performed in 54 patients. Lumbar puncture for CSF analysis was performed in 57/67 (85.0\%) patients.

The acute treatment for each of these patients at presentation and subsequent episodes of relapses was decided by the treating pediatricians, on the basis of protocols influenced by their regional and/or national reference center for CNS demyelination, guided by severity and persistence of symptoms. Disease-modifying therapies (DMTs) referred to all forms of maintenance immunomodulation or immunosuppression therapies.

Annualized relapse rates (ARRs) on retrospective data were calculated as number of relapses per year and only included patients with at least 6 months of follow-up after initiation of treatment. If time to treatment was less than 6 months, the pretreatment ARR was calculated over a 6-month period. The outcomes, as measured by a range of difficulties the patients were experiencing (cognitive, visual, and motor), at last follow-up were retrieved from the patient's medical records to represent the most contemporary assessment of disability. If unavailable, this assessment was obtained directly from the patient's primary treating physician. Patients were considered to have motor disability if they were a wheelchair user, needed crutches (or a cane) to walk, or could walk for less than $500 \mathrm{~m}$ without support. Cognitive performance was estimated by looking at their school performance at last follow-up: patients were considered to have cognitive difficulties if there was significant school support, grade repetition, or needing of special education schools. Patients were considered to have visual sequelae if the logMAR scale was $<0.3$ (Snellen $<20 /$ $40)$ or persistent visual field defects. The Expanded Disability Status Scale (EDSS) scores were documented at first attack nadir and at final follow-up (at point of disease stability at least 3 months from acute or relapsing events).

All CRFs were initially reviewed by the respective national leads and subsequently analyzed by 3 investigators (R.B.P., Y.H., and K.D.).

\section{AQP4-Ab testing}

Within 1 month of an acute event (either onset or relapse), clinically symptomatic children underwent testing for serum $\mathrm{AQP} 4-\mathrm{Ab}$, using live cell-based assays in the respective reference laboratories of the following referring countries (France, $^{18}$ Brazil, $^{19}$ United Kingdom, ${ }^{20}$ Spain, ${ }^{21}$ the Netherlands, ${ }^{22,23}$ in Germany/Austria in the Clinical Department of Neurology, Medical University of Innsbruck, Innsbruck, Austria and in Italy and Ukraine anti-AQP4 
antibodies testing were performed with commercial IFA [Euroimmun]). Routine assessments of antibody testing in the CSF were not performed.

\section{Statistical analysis}

We tested the hypothesis that patients treated with AZA, $\mathrm{MMF}$, and/or rituximab experienced a reduction in ARR providing Class IV evidence for therapeutic decision.

Descriptive data of demographic, clinical, radiologic, and serologic characteristics were reported for children with AQP4$\mathrm{Ab}$ NMOSD. To compare between the different ethnicities, parametric or nonparametric statistical tests (Mann-Whitney $U$ and Kruskal-Wallis tests) were used for continuous distributions, as appropriate given normality, and $\chi^{2}$ or Fisher exact tests for nominal data. In particular, comparisons between White and non-White ethnicities and stratified EDSS score at last follow-up were performed. Logarithm transformation was performed for nonparametric data. Effect sizes were calculated by OR, Cohen d, and eta-squared $\left(\eta^{2}\right)$ measures.

In addition, parametric or nonparametric statistical tests were used for continuous distributions, as appropriate, and $\chi^{2}$ or Fisher exact tests for nominal data to compare patients who were treated with AZA, MMF, and rituximab as first-line treatment. A paired 2-tailed $t$ test was used to compare ARRs before and during treatment.

Univariate logistic regression was used to evaluate age at onset, sex, ethnicity, demyelinating phenotype at onset, abnormal MRI at onset, time to treatment, number of relapses before treatment, and follow-up duration as potential predictors of motor (wheelchair or walking aid), visual (blindness), and cognitive outcomes at last follow-up. Multivariable analyses were modeled for the same outcomes, including as covariates those variables significant at the $(p<0.05)$ level in the univariate analysis. Results were presented as ORs and 95\% CIs. A 2 -sided $p<0.05$ was considered significant. Data were analyzed using SPSS 20 software and GraphPad Prism 5.

\section{Data availability}

Anonymized data will be shared by request from qualified investigators.

\section{Results}

\section{Patients}

A total of 67 children with AQP4-Ab NMOSD were included in this study (table 1). Mean age at onset was $10.2 \pm 3.6$ years (range 2-16 years). The female/male ratio was 4.1:1. Of the 67 children, 29 (43.3\%) were White, 14 (20.9\%) Black, 13 (19.4\%) Brazilian mixed ethnicity, and 11 (16.4\%) other ethnicities. Of the 67 children, 29 (43.3\%) were White, 14 (20.9\%) Black, 13 (19.4\%) Brazilian mixed ethnicity and 11 (16.4\%) other ethnicities (Asian, Indians, Nepali, AfroCaribbean, Omani). Non-White ethnicity was more common in both European (25/47) and Brazilian (13/20) populations.
Family history of autoimmune diseases was reported in 9 (13.7\%) patients, personal history of inflammatory diseases in $7(10.4 \%)$, and $8(11.9 \%)$ had a preceding infection. Patients' demographic, clinical, and paraclinical features and EDSS scores, stratified to ethnicities, are summarized in table 1 . The groups were similar except for shorter time to first relapse $\left(\eta^{2}\right.$ $=0.071, p=0.049)$ and higher EDSS score at last follow-up $\left(\eta^{2}=0.056, p=0.008\right)$ in the non-White population.

\section{First attack features}

The most frequent phenotype at onset was isolated $\mathrm{ON}(\mathrm{n}=20$, $29 \%)$ followed by isolated TM $(n=15,22 \%)$ and isolated area postrema syndrome $(n=11,16.4 \%)$. Of the children presenting with ON, 9/20 (45\%) had bilateral ON. Of the 15 children presenting with isolated TM, $10(66.7 \%)$ had longitudinally extensive TM. Six (9\%) patients had simultaneous ON and TM. Six (9\%) patients presented with ADEM, 1 (1.5\%) patient with isolated diencephalic syndrome, 3 (4.5\%) with isolated brainstem syndrome, and 5 (7.5\%) patients with multifocal syndromes involving the spinal cord, optic nerve, and brain (brainstem, area postrema, or diencephalic syndromes).

At onset, 44/61 (72.1\%) patients had abnormal brain MRI, $32 / 50$ (64\%) patients had abnormal spinal cord MRI, and 16/ 54 (29.6\%) had contrast-enhancing lesions. Abnormal CSF was reported in $37 / 57(64.9 \%)$ children, with oligoclonal bands detected in $7 / 57$ (12.2\%). CSF pleocytosis was present in $35 / 50(70 \%)$ examinations, with a median of 10 cells (interquartile range $[\mathrm{IQR}] 2.5-38.5$ cells). Elevated CSF protein was found in $13 / 27(48 \%)$ examinations with a median of $0.030 \mathrm{~g} / \mathrm{dL}$ (IQR $0.002-0.850 \mathrm{~g} / \mathrm{dL}$ ). Myelin oligodendrocyte glycoprotein antibodies (MOG-Abs) were negative in the 60 patients who were tested.

\section{Disease course and outcome}

A total of 297 attacks were reported in the cohort. The median time to first relapse was 4 months (range 1.7-100.5 months). At last follow-up (median disease duration of 4 years, IQR 2-10 years), $58(86.6 \%)$ patients had a second clinical event with a median ARR of 1.05 relapses per year and median (IQR) EDSS score $=2.0(1.0-3.5)$. Moderate disability with EDSS score $\geq 3$ was reported in 29/67 (43.2\%). Visual impairment was seen in $32(47.8 \%)$ patients, of which 20 were registered blind (visual acuity $<20 / 200$; $\log$ MAR $>1$ ), motor deficits were found in 14 (21.2\%, of which 5 were wheelchair users and 2 used a walker), and cognitive impairment was detected in 17 (25.4\%) patients.

A more severe disease course was seen in the non-White ethnicity with worse EDSS score at last follow-up $(p=0.008)$ and a shorter time to first relapse $(p=0.049)$.

\section{Response to immunotherapy}

DMTs were given in 63/67 (95\%) children. A total of 41 patients were treated with $1 \mathrm{DMT}, 12$ with 2, 7 with $3 \mathrm{DMTs}$, 2 with 4 DMTs, and 1 with 5 sequential DMTs. Patients were commenced on DMTs at a median of 6 months from 
Table 1 Clinical/paraclinical features and outcome in children with AQP4-Ab NMOSD stratified to the different ethnicities

\begin{tabular}{|c|c|c|c|}
\hline & White $(N=29)$ & Non-White $(\mathrm{N}=38)$ & All $(N=67)$ \\
\hline Age at onset, y, mean (SD) & $10.6(3.5)$ & $9.9(3.7)$ & $10.2(3.6)$ \\
\hline Female sex, $\mathrm{n}(\%)$ & $25 / 29(86.2)$ & 29/38 (76.3) & $54 / 67(80)$ \\
\hline EDSS score at nadir, median (IQR) & $\mathrm{N}=17 ; 3.0(2-4.5)$ & $\mathrm{N}=30 ; 4.7(3.3-7.5)$ & $\mathrm{N}=47 ; 4.0(3-6.5)$ \\
\hline \multicolumn{4}{|l|}{ Baseline attack } \\
\hline Area postrema syndrome (all), n (\%) & $8 / 29(27.6)$ & $6 / 38(15.8)$ & 14/67 (21) \\
\hline Optic neuritis presentation (all), $n$ (\%) & $15 / 29(51.7)$ & $14 / 38(36.8)$ & 29/67 (43) \\
\hline Transverse myelitis presentation (all), $\mathrm{n}(\%)$ & $10 / 29(34.5)$ & $14 / 38(36.8)$ & $24 / 67(36)$ \\
\hline Brainstem/cerebral involvement (all), n (\%) & $9 / 29(31)$ & $17 / 38(44.7)$ & 26/67 (39) \\
\hline Abnormal brain MRI at onset, $n$ (\%) & 20/27 (74.1) & 24/34 (70.6) & $44 / 61(72)$ \\
\hline Abnormal spinal cord MRI at onset, $n$ (\%) & $14 / 21(66.7)$ & 17/29 (58.6) & $31 / 50(62)$ \\
\hline Intrathecal OCB, n (\%) & $3 / 22(13.6)$ & $4 / 23(17.4)$ & $7 / 47(15)$ \\
\hline Time to first relapse, mo, median (IQR) & $5.5(3-14.2)$ & $4(2-5)$ & $4(2-10)$ \\
\hline No. of attacks, median (IQR) & $3(2-5.7)$ & $2(2-5)$ & $3(2-5)$ \\
\hline No. of attacks in the first $2 y$, mean (SD) & $2.2(1.3)$ & $2.1(0.9)$ & $2.2(1.1)$ \\
\hline Time to treatment, mo, median (IQR) & $6(2-17)$ & $4.5(1-10.2)$ & $5(1-13.5)$ \\
\hline FU, y, median (IQR) & $6(4-10.7)$ & $3.5(2-6.2)$ & $4(2-10)$ \\
\hline Visual sequelae, $\mathbf{n}(\%)$ & $14 / 29(48.3)$ & $18 / 35(51.4)$ & $32 / 64(50)$ \\
\hline Motor sequelae, n (\%) & $5 / 29(17.2)$ & 9/37 (24.3) & $14 / 66(21)$ \\
\hline Cognitive sequelae, $\mathbf{n}(\%)$ & $5 / 28(17.9)$ & 12/38 (31.6) & $17 / 66(26)$ \\
\hline EDSS score at last FU, median (IQR) & $2.0(0-3)$ & $2.5(1-4)$ & $2.0(1-3.5)$ \\
\hline
\end{tabular}

Abbreviations: EDSS, Expanded Disability Status Scale; FU, follow-up; IQR = interquartile range; OCB = oligoclonal band.

symptom onset (IQR 2-13.5 months) and a median of 2 clinical attacks (IQR $1-3$ clinical attacks). Of the 4 untreated patients, at a median follow-up of 5 years (range 2-10 years), only 1 patient relapsed despite persistent antibody positivity.

A total number of 139 relapses on treatment were observed in the cohort. Relapses occurred on all treatments, except the 2 patients treated with ofatumumab and the 1 patient who underwent hematopoietic stem cell transplantation (HSCT). The clinical course and disease activity in patients who underwent therapy with maintenance treatment are illustrated in figure 1. Most frequently used treatments were AZA (total treatment duration 209.5 patient years, relapses $=92 ; 0.43$ relapses/treated year), rituximab (total treatment duration 88 years, relapses $=13 ; 0.15$ relapses $/$ treated year), and MMF (total treatment duration 46.2 years, relapses $=23 ; 0.49$ relapse/treated year). Patient characteristic stratified to firstline treatments is summarized in table 2 and table e-4, links. lww.com/NXI/A287.

Thirty-nine children were treated with AZA, 35 (89.7\%) as first-line therapy, and 4 as second-line treatment. AZA treatment was associated with a mean reduction in the ARR of 1.10 (mean ARR pretreatment 1.69 vs 0.59 on treatment, mean difference 1.10, 95\% CI 0.54-1.66, $t=4.01$, Cohen $\mathrm{d}=0.63, p<$ $0.001)$. Twenty-five of 39 (64.1\%) patients relapsed on treatment. Of these, treatment was escalated in 16 patients to MMF $(\mathrm{n}=6)$, rituximab $(\mathrm{n}=8)$, cyclosporine $(\mathrm{n}=1)$, and glatiramer acetate $(n=1)$. Of the 4 who were treated with AZA as second line, 3 previously failed treatment with methotrexate, glatiramer acetate, and cyclophosphamide, and in 1, treatment was deescalated after being relapse free on rituximab.

Twenty-nine children were treated with rituximab, 14 (48.3\%) first line, 9 (31.0\%) second line, 5 (17.2\%) third line, and 1 (3.4\%) fourth line. The treatment with rituximab was associated with a mean reduction in the ARR of 2.36 (mean ARR pretreatment 2.50 vs 0.14 on treatment, mean difference 2.36, 95\% CI 1.57-3.15, $t=6.13$, Cohen $\mathrm{d}=1.14, p<0.001$ ). All 14 patients treated with rituximab as first line did not have further relapses. Of these, 1 patient had prolonged oral steroids (for 1 year) before commencing rituximab, and a second patient had additional intravenous immunoglobulin for the first 6 months. Seven of 29 patients (24.1\%) treated with 


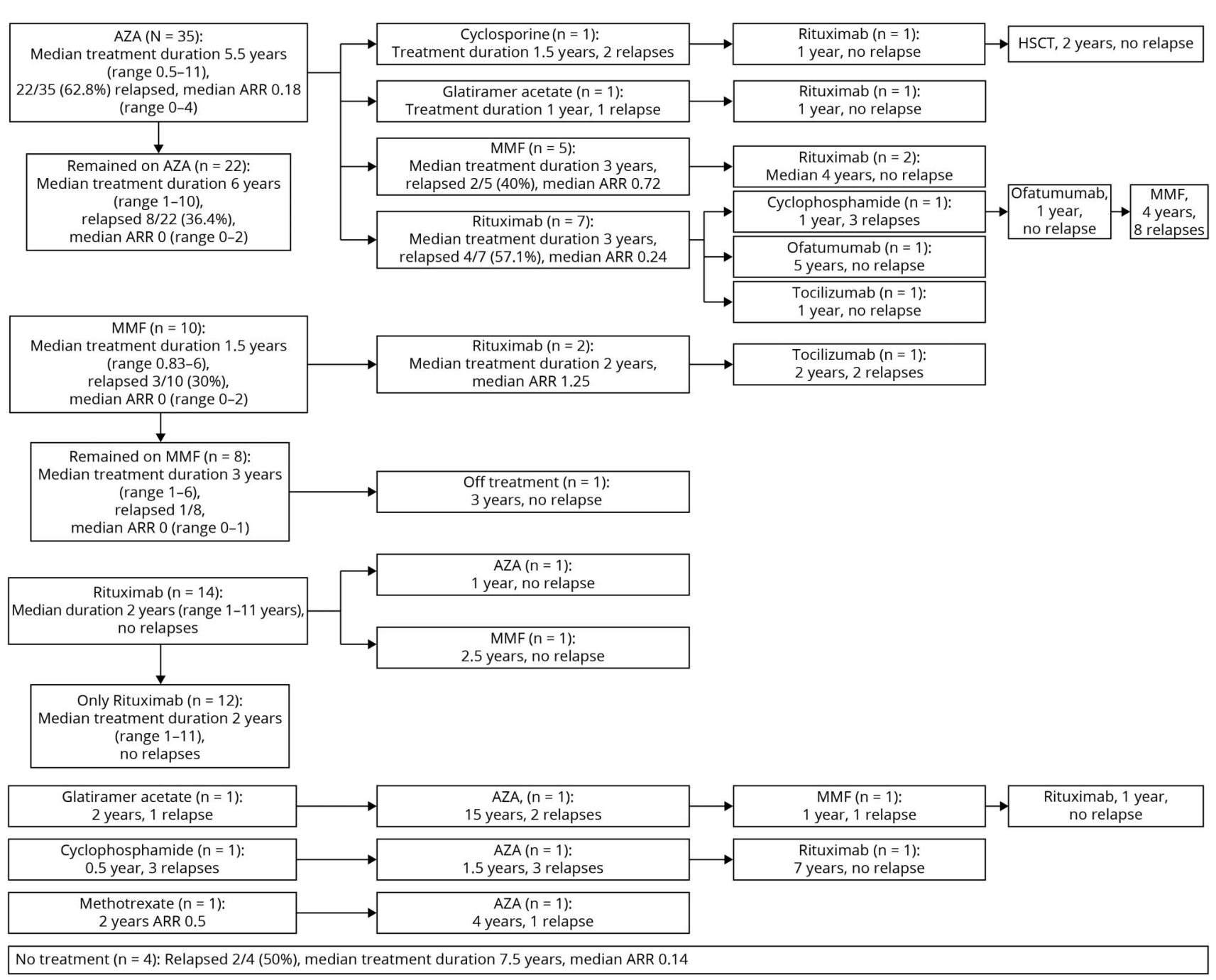

Patient relapsed on all treatments with a total of 139 relapses on treatment reported in the cohort. Forty-three (69.3\%) remained relapse free on treatment; 10/35 (28.6\%) treated with azathioprine (AZA), 10/17 (58.8\%) treated with mycophenolate mofetil (MMF); and 23/29 (79.3\%) treated with rituximab. One patient who relapsed AZA and cyclosporine underwent hematopoietic stem cell transplantation (HSCT) and has not relapsed (follow-up 2 years).

rituximab relapsed on treatment, and these patients were previously treated with AZA $(n=5)$ and MMF $(n=2)$. In the 4 children in whom the CD19 count was measured acutely, 1 relapsed with absent $B$ cells and 3 during $B$ cell reconstitution.

Eighteen children were treated with MMF, 10 (55.6\%) first line, $6(33.3 \%)$ second line, 1 (5.6\%) third line, and 1 fifth line (5.6\%). MMF treatment was associated with a mean reduction in the ARR of 0.32 (mean ARR pretreatment 1.04 vs 0.72 on treatment, mean difference 0.32 , $95 \% \mathrm{CI}-0.57$ to 1.22, $t=0.77$, Cohen $\mathrm{d}=0.18, p=0.452$ ). Ten patients remained relapse free on treatment. Of the 8 who relapsed on treatment, 5 were changed to rituximab.

Tocilizumab was used in 2 patients as third-line DMT, and both relapsed and satralizumab in 2 patients (who were enrolled in the open-label SAkuraSky trial as an add-on treatment to MMF), who have not relapsed. Two patients were treated with ofatumumab following infusion reaction with rituximab and have not relapsed. Three patients treated with cyclophosphamide, 2 with methotrexate and 1 with cyclosporine; all continued to relapse with worsening ARR. Two patients were treated with glatiramer acetate for a presume diagnosis of MS, and both relapsed on treatment. ARRs before and after treatment initiation are shown in figure 2 .

\section{Adverse events}

Of the 37 patients treated with AZA, 5 (13.5\%) developed lymphopenia $\left(<0.5 \times 10^{9} / \mathrm{L}\right)$ without infectious complications, 3 developed infections (viral meningitis, pneumonia, and varicella), and 3 did not tolerate the treatment in view of gastrointestinal symptoms or raised liver function test. One child developed lymphopenia $\left(<0.5 \times 10^{9} / \mathrm{L}\right)$ on MMF. Infusion reactions with rituximab occurred in 3 of 29 (10.3\%) children, of which 2 were switched to ofatumumab due to the 
Table 2 Patients characteristic stratified to first-line treatment

\begin{tabular}{|c|c|c|c|c|}
\hline & $\begin{array}{l}\text { Azathioprine } \\
(\mathrm{n}=35)\end{array}$ & $\begin{array}{l}\text { Mycophenolate } \\
\text { mofetil }(n=10)\end{array}$ & $\begin{array}{l}\text { Rituximab } \\
(n=14)\end{array}$ & $\begin{array}{l}\text { Other treatment/no } \\
\text { treatment }(n=8)\end{array}$ \\
\hline $\begin{array}{l}\text { Age when starting treatment, } y \text {, } \\
\text { median (range) }\end{array}$ & $11(4-17)$ & $9(3-17)$ & $12(5-15)$ & $11(9-15)$ \\
\hline Non-White ethnicity, n (\%) & $21 / 35(60)$ & $4 / 10(40)$ & $8 / 14(57,1)$ & $3 / 8(37.5)$ \\
\hline \multicolumn{5}{|l|}{ Country of origin, $n(\%)$} \\
\hline Brazil $(n=20)$ & $17 / 20(85)$ & $1 / 20(5)$ & 0 & $2 / 20(10)$ \\
\hline United Kingdom $(n=18)$ & $7 / 18(38.9)$ & $5 / 18(27.8)$ & $3 / 18(16.7)$ & $3 / 18(16.7)$ \\
\hline France $(n=10)$ & $2 / 10(20)$ & $1 / 10(10)$ & $6 / 10(60)$ & $1 / 10(10)$ \\
\hline Spain $(n=6)$ & $2 / 6(33.3)$ & $1 / 6(16.7)$ & $3 / 6(50)$ & 0 \\
\hline Germany/Austria $(n=5)$ & $4 / 5(80)$ & 0 & $1 / 5(20)$ & 0 \\
\hline Belgium/the Netherlands/Italy/Ukraine $(n=8)$ & $3 / 8(37.5)$ & $2 / 8(25)$ & $1 / 8(12.5)$ & $2 / 8(25)$ \\
\hline \multicolumn{5}{|l|}{ Demyelinating phenotype at onset, $\mathrm{n}(\%)$} \\
\hline Optic neuritis $(n=29)$ & $16 / 29(55.1)$ & $7 / 29(24.1)$ & $4 / 29(13.7)$ & $2 / 29(6.8)$ \\
\hline Transverse myelitis $(n=24)$ & $13 / 24(54.1)$ & $2 / 24(8.3)$ & $7 / 24(29.1)$ & $2 / 24(8.3)$ \\
\hline All area postrema syndrome (14) & $7 / 14(50)$ & $1 / 14(7.1)$ & $4 / 14(28.5)$ & $2 / 14(14.2)$ \\
\hline All brainstem/encephalic $(n=26)$ & $13 / 26(50)$ & $3 / 26(11.5)$ & $6 / 26(23)$ & $4 / 26(15.3)$ \\
\hline Time to treatment, mo, median (range) & $6(0-84)$ & $6(0-16)$ & $1(0-9)$ & - \\
\hline $\begin{array}{l}\text { No. of attacks before treatment, median (range), } \\
\text { n (\%) }\end{array}$ & $2(1-6)$ & $2(2-4)$ & $2(1-9)$ & - \\
\hline $\begin{array}{l}\text { Median duration on treatment, y, median } \\
\text { (range) }\end{array}$ & $5.5(0.5-11)$ & $1.5(0.8-6)$ & $2(1-11)$ & - \\
\hline ARR, median (range) & $0.18(0-4)$ & $0(0-2)$ & 0 & - \\
\hline No. of patients who relapsed on treatment, $n(\%)$ & $22 / 35(62.8)$ & $3 / 10(30)$ & 0 & - \\
\hline No. of patients who changed treatment, $n(\%)$ & $14 / 35(40)$ & $\begin{array}{l}2 / 10(20) \\
\text { additional } \\
\text { one stopped }\end{array}$ & $2 / 14(14.2)$ & - \\
\hline
\end{tabular}

Abbreviation: ARR = annualized relapse rate.

side effects. One child developed persisted neutropenia on rituximab and was changed to AZA.

\section{Predictors of poor outcome}

ORs to estimate the effects of parameters at onset on the occurrence of disability (EDSS score $\geq 3$ ) are illustrated in table 2. Children with an EDSS score $\geq 3(n=29,43.2 \%)$ were younger, presented with ON, and had a higher EDSS score at nadir. Patients with a better outcome at last follow-up (EDSS score $<3.0$ ) were more commonly girls and presented with cerebral syndrome (table 3 ). Logistic regression looking at age at onset, ethnicity, demyelinating phenotype at onset, abnormal MRI at onset, time to treatment, and number of relapses before treatment were evaluated as predictors of motor, visual, and cognitive outcomes (table e-1, links.lww. com/NXI/A284, table e-2, links.lww.com/NXI/A285, and table e-3, links.lww.com/NXI/A286). Multivariable analysis did not identify any predictors for motor disabilities (wheelchair or walking aid). $\mathrm{ON}$ at onset was associated with worse visual outcome below 20/200 ( $p=0.008$, OR 8.669, 95\% CI 1.764-42.616), and younger age at onset was associated with worse cognitive impairment $(p=0.018$, OR $0.786,95 \%$ CI 0.644-0.959).

\section{Discussion}

AQP4-Ab NMOSD is now well recognized in children. Natural history studies suggest an attack-related stepwise accumulation of disabilities. Therefore, attack prevention strategies are used as maintenance treatment. In this multinational cohort of children with AQP4-Ab NMOSD, the phenotype observed was overall similar to that reported previously in children or adults. ${ }^{3}$ The time to first relapse was 
Figure 2 The efficacy of various disease-modifying therapies in children with AQP4-Ab NMOSD
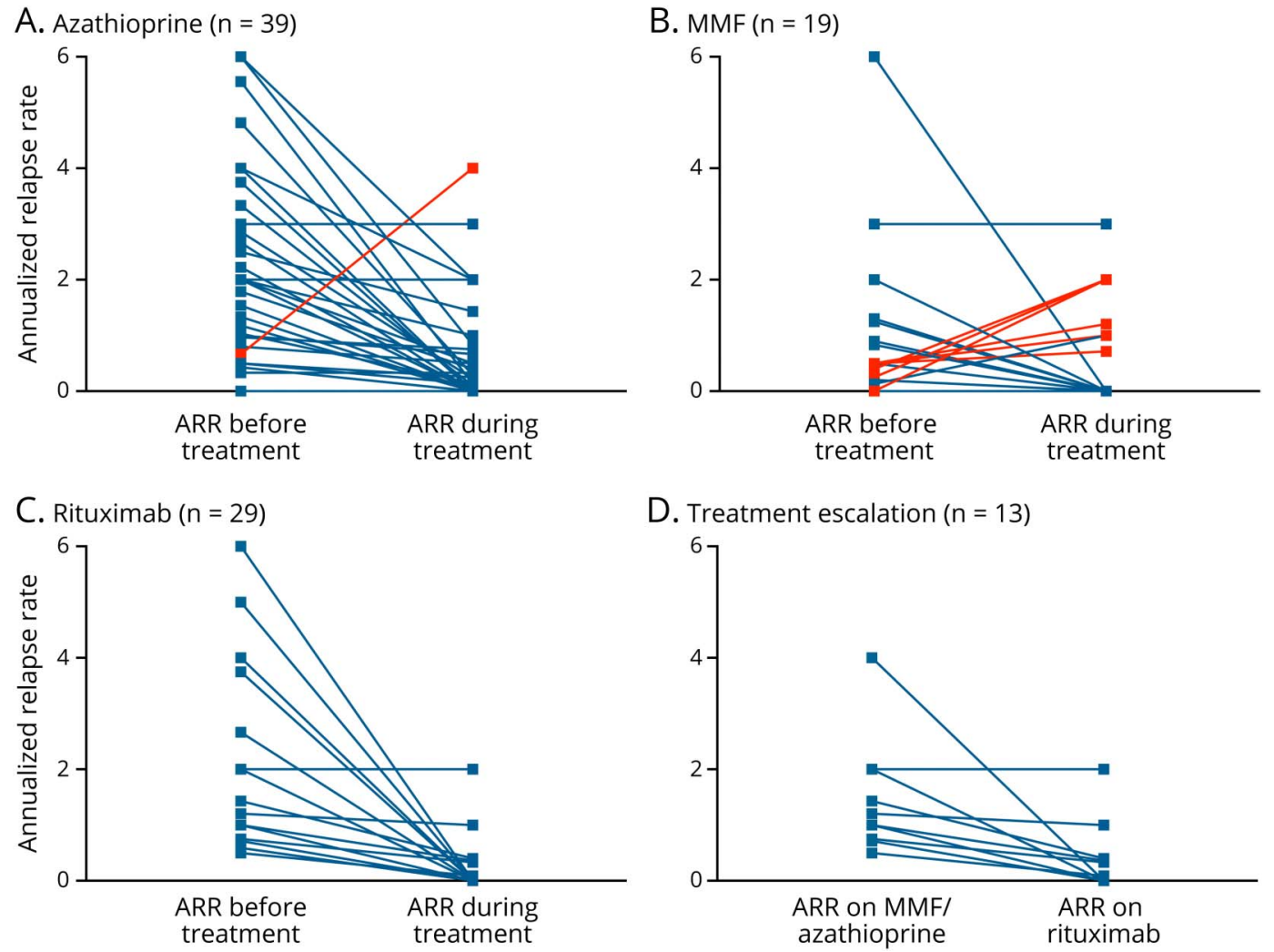

Annualized relapse rates (ARRs) before and after treatment initiation with the most frequently used medications. (A) Azathioprine (AZA). (B) Mycophenolate mofetil (MMF). (C) Rituximab. (D) After escalation from treatment with AZA or MMF to rituximab.

short, and the ARR pretreatment was high, indicating a high risk of relapses and permanent disability in children with AQP4-Ab NMOSD.
We detected cognitive impairment in $25.4 \%$ of the cohort. Abnormal brain MRI was not a risk factor, but younger age at onset and brainstem/cerebral attacks were associated with

Table 3 Univariable analysis and OR for parameters associated with the EDSS score (EDSS $\geq 3$ ) at final follow-up

\begin{tabular}{|c|c|c|c|c|}
\hline & EDSS score $<3(n=38)$ & EDSS score $\geq 3(n=29)$ & OR $(95 \% \mathrm{Cl})$ & $p$ Value \\
\hline Sex (F:M) & $34: 4$ & $20: 9$ & $0.261(0.071-0.960)$ & 0.043 \\
\hline Age at presentation, $y$, mean (SD) & $11.1(3.1)$ & $9.1(3.9)$ & $0.847(0.732-0.980)$ & 0.026 \\
\hline Ethnicity (White:non-White) & 19:19 & $10: 19$ & $1.900(0.702-5.141)$ & 0.206 \\
\hline Optic neuritis presentation, $\mathbf{n}(\%)$ & $12 / 38(31.6)$ & $17 / 29(58.6)$ & $3.069(1.121-8.402)$ & 0.029 \\
\hline Transverse myelitis presentation, $\mathbf{n}(\%)$ & $12 / 38(31.6)$ & $12 / 29(41.4)$ & $1.529(0.559-4.186)$ & 0.408 \\
\hline Brainstem/cerebral presentation, $\mathbf{n}(\%)$ & $19 / 38(50)$ & $7 / 29(24.1)$ & $0.318(0.110-0.920)$ & 0.035 \\
\hline Abnormal brain MRI, n (\%) & 25/35 (71.4) & 19/26 (73.1) & $1.096(0.349-3.379)$ & 0.887 \\
\hline Intrathecal OCBs, n (\%) & $7 / 28(25)$ & $0 / 17$ & NA & $>0.999$ \\
\hline EDSS score at nadir, mean (SD) & $N=26 ; 4.0(2.3)$ & $N=21 ; 5.4(2.2)$ & $1.303(1.004-1.690)$ & 0.046 \\
\hline Time to treatment, mo, median (IQR) & $6(1.5-16)$ & $4.5(1-10.7)$ & $1.003(0.967-1.041)$ & 0.859 \\
\hline No. of relapses before treatment, median (IQR) & $1(0.2-2)$ & $1(0-2)$ & $1.061(0.749-1.503)$ & 0.739 \\
\hline FU, y, median (IQR) & $4(3-6)$ & $5(2-12)$ & $1.1109(1.009-1.218)$ & 0.032 \\
\hline
\end{tabular}

Abbreviations: $\mathrm{Cl}=\mathrm{Cl}$ for OR calculated for nominal variables; EDSS = Expanded Disability Status Scale; FU = follow-up; IQR = interquartile range; OCB = oligoclonal band. 
cognitive deficits. Cognitive impairment had not been systematically addressed in pediatric NMOSD, and our results highlight its importance. Although no objective cognitive measure was used in this study, we selected measures that are consistent across the diverse educational systems that reflect clear difficulties and thus would be a reasonable surrogate for cognitive performance. $\mathrm{ON}$ at onset was a risk for visual impairment and blindness in keeping with previous report that young children do not recover well following $\mathrm{ON} .{ }^{16}$ Of interest, time to starting treatment and number of relapses before starting treatment were not associated with worst outcome. As previously reported, ${ }^{24}$ non-White ethnicity was associated with a more aggressive disease course but was not predictive of moderate disabilities at last follow-up.

Patients were treated according to each center experience, and the choices of treatment were additionally influenced by the access to treatments in each country and their related costs. Almost all of the Brazilian children were commenced on AZA, and none were given rituximab as first-line treatment. In contrast, the European children were frequently commenced on rituximab and MMF (table 3). A previous pediatric cohort $^{10}$ (only 20/58 patients were treated with DMTs) reported residual disability in $43 / 48$ (90\%), with $26 / 48$ (54\%) having visual impairment and 21/48 (44\%) with motor deficits. Comparing to this cohort, the visual but not the motor outcome is similar, which might be related to treatment.

A key observation from our study was that all treatments known to reduce relapses in adults (AZA, MMF, and rituximab) were associated with a reduction in the ARR. Moreover, rituximab treatment resulted in the lowest $A R R$, and it is remarkable that all 14 patients who started on rituximab as first line did not have any further relapses. Treatment escalation from AZA and MMF to rituximab was beneficial in 12/ 13 , with only 1 child maintaining the same ARR (figure 2). The benefit of early treatment with rituximab was previously demonstrated in a pediatric cohort with a range of CNS disorders including NMOSD. ${ }^{25}$ This apparent superiority could be partially explained by the early treatment effect of rituximab. In addition, in our cohort, patients were also initiated with rituximab sooner compared with AZA/MMF ( 1 month vs 6-10 months) after the attack. CD19 count was not performed in all 7 patients who relapsed with rituximab. Monitoring B-cell repopulation and redosing rituximab might prevent relapses as demonstrated in a pediatric study. ${ }^{26}$ Three patients treated with rituximab changed therapy due to adverse effect, and none had severe infection. Prospective follow-up was not performed to check on hypogammaglobulinemia. ${ }^{27}$

Although we did not perform a direct comparison, the treatment effect observed in this pediatric cohort appeared greater than reported in adults with AQP4-Ab NMOSD., ${ }^{6-30}$ The greater reduction in the ARR following initiation of DMTs is also reported in children with MS compared with adults and likely reflects the more inflammatory disease seen in the younger patients. ${ }^{31}$ Of interest, in comparison to a cohort of children with MOG-Ab-associated disease, ${ }^{32}$ despite the higher ARR before treatment, the ARR on treatment was lower across all treatments in the AQP4-Ab NMOSD group.

Our cohort was not optimal for a direct evaluation of an individual treatment or a sequence of treatment effect, which is better suited to a study design where the sequence of DMTs, the lag phase of efficacy or washout period of specific therapies are prospectively controlled. One particular treatment that deserves specific attention would be the cumulative use of corticosteroids, often used in conjunction with DMTs and at low doses, but also during acute attacks. Time to initiation of acute treatment, the choice of treatment, and treatment escalation are major predictors of long-term outcome in AQP4-Ab NMOSD. ${ }^{33-35}$ As many of the children presented initially to district general hospital, timing, duration, and sequence of acute treatment were not included in the analysis.

A major limitation of this study is that not all patients were systematically managed, with possible biases in treatment initiation and/or escalation. Nevertheless, these real-world clinical data from multiple countries allowed us to make important observations about the treatment responsiveness of children with AQP4-Ab NMOSD. The important question our study raises is whether rituximab should be first-line treatment for children. Moreover, should children who are already stable on AZA and MMF be changed to the more efficacious therapies with a higher risk profile? Furthermore, with new monoclonal antibodies (satralizumab, ${ }^{36}$ inebilizu$\mathrm{mab}^{37}$ and eculizumab ${ }^{38}$ ) likely to become available, treatment algorithms that accommodate risk stratification of poorer prognosis (such as the patients age and severity of the attack) and grouping of treatments with similar efficacy within the sequence and choice of treatments in pediatric AQP4-Ab NMOSD are urgently required.

\section{Acknowledgment}

The authors thank all collaborators who worked in this study in the collection of data: Austria and Germany: M. Reindl, Clinical Department of Neurology, Medical University of Innsbruck, Innsbruck, Austria. Brazil: Dr. Dagoberto Callegaro (Department of Neurology, Hospital das Clínicas, Faculty of Medicine, São Paulo, Brazil). Laboratory of Brain Institute of Rio Grande do Sul (Brains), Pontifical Catholic University of Rio Grande Do Sul (PUCRS), Porto Alegre, Brazil. France: Dr. Maurey, Assistance Publique-Hôpitaux de Paris, University Hospitals Paris South, Bicêtre Hospital, Pediatric Neurology Department, Le Kremlin Bicêtre, Dr. Pascale Chrétien, University Hospitals Paris South, Bicêtre Hospital, Immunology Department, Le Kremlin Bicêtre, Dr. Aubart, Assistance Publique-Hôpitaux de Paris, Necker Hospital, Paris, Dr. Cheuret, Hôpital des Enfants, Pediatric Neurology Department, Toulouse, Dr. Lepine, Centre Hopitalo-Universitaire de Marseille, Marseille, Pr Laugel, CHU de Strasbourg - Hôpital de Hautepierre, Pediatric Neurology 
Department, Strasbourg. Spain: Dr. Maria Sepulveda (Neuroimmunology Program, Hospital Clinic-IDIBAPS, University of Barcelona, Spain), Dr. Victor Soto-Insuga (Pediatric Neurology Section, Pediatric Service, Fundacion Jimenez Díaz, Madrid, Spain), Maria C. Miranda-Herrero (Pediatric Neurology Section, Pediatric Service, Hospital Gregorio Marañon, Madrid, Spain), Montserrat Garcia-Puig (Pediatric Neurology Section, Pediatric Service, Hospital Parc Taulí, Sabadell, Spain). The Netherlands: Prof. Rogier Hintzen, MD, $\mathrm{PhD}$, was involved in this study before his sudden death. Dörte Hamann and Kyra Gelderman from the Department of Immunopathology and Blood Coagulation, Sanquin Diagnostic Services, Amsterdam, the Netherlands. AQP4 antibodies were routinely assayed in a cell-based assay using a fluorescence-activated cell sorter (FACS, LSRII, and DIVA software, Becton Dickinson, San Jose). United Kingdom: UK Childhood Inflammatory Disorders (UK-CID) Study Group: Antonia Clarke, MD (Department of Paediatric Neurology, St George's Hospital, London), Katherine Forrest, MD (Department of Paediatric Neurology, Southampton Children's Hospital, Southampton), Andrex Lux, MD (Department of Paediatric Neurology, University Hospitals Bristol, Bristol), Saleel Chandratre, MD (Department of Paediatric Neurology, John Radcliffe Hospital, Oxford), Kshitij Mankad, MD, and Kling Chong, MD (Paediatric Neuroradiology, Great Ormond Street Hospital, London). Laboratory: Paddy Water, $\mathrm{PhD}$, Mark Woodhall, $\mathrm{PhD}$, and Jackie Palace, $\mathrm{MD}, \mathrm{PhD}$ (Oxford Autoimmune Neurology Group and National Health Service National Specialised Commissioning Group for Neuromyelitis Optica, United Kingdom).

\section{Study funding}

This study was supported in part by the Marato TV3 Foundation (20141830 to T.A. and A.S.), Red Española de Esclerosis Múltiple (REEM) (RD16/0015/0002; RD16/0015/ 0003 to A.S.), and Torrons Vicens Foundation (PFNR0144 to TA).

\section{Disclosure}

R.B. Paolilo received support for participating in scientific meetings from Roche and Merck. Y. Hacohen and E. Yazbeck report no disclosures. T. Armangue received speaking honoraria from Novartis and travel expenses for participating in scientific meetings from Roche. A. Bruijstens and C. Lechner report no disclosures. S.L. Apostolos-Pereira served as board advisory for Novartis and Roche and received support for participating in scientific meetings from Genzyme, Roche, and Novartis. Y. Martynenko, M. Breu, C. de Medeiros Rimkus, E. Wassmer, M. Baumann, and L. Papetti report no disclosures. M. Capobianco received personal honoraria for speaking at meeting or participating in advisory boards from Biogen, Merck, Novartis, Roche, Sanofi, and Teva. B. Kornek, K. Rostásy, and J.A. da Paz report no disclosures. O. Ciccarelli receives research funding from the UK MS Society, Rosetrees Trust, and NIHR UCLH BRC and serves as a consultant for Biogen, Novartis, Roche, and GE Healthcare; she is on the editorial board of Neurology. M. Lim received consultation fees from CSL Behring; received travel grants from Merck
Serono; and was awarded educational grants to organize meetings by Novartis, Biogen Idec, Merck Serono, and Bayer. A. Saiz reports no disclosures. R. Neuteboom received consultation fees from Novartis and Zogenix. R. Marignier serves on the scientific advisory board for Novartis and MedImmune and received speaker honoraria and travel funding from Novartis, Biogen, Teva, Sanofi-Aventis/Genzyme, and Merck. C. Hemingway received consulting and educational grants from Novartis; served on the Global Paediatric MS Steering committee and received educational grants from Biogen; and received consultation fees from Alexion. D.K. Sato received research support from CAPES/Brasil, $\mathrm{CNPq} /$ Brasil, FAPERGS/Brasil, and Japan Society of Science and received speaker honoraria from Biogen, Novartis, Genzyme, Merck Sereno, Quest/Athena Diagnosis, Shire, and Teva. K. Deiva received speaking honoraria at meetings and for participation in advisory boards from Novartis, Sanofi, and Servier. Go to Neurology.org/NN for full disclosures.

\section{Publication history}

Received by Neurology: Neuroimmunology \& Neuroinflammation March 2, 2020. Accepted in final form April 28, 2020.

Appendix Authors

\begin{tabular}{lll}
\hline Name & Location & Contribution \\
\hline Renata & Department of Neurology, & Analyzed data and \\
Barbosa & Hospital das Clínicas, & drafted the manuscript \\
Paolilo, MD & Faculty of Medicine, & for intellectual content \\
& $\begin{array}{l}\text { University of São Paulo } \\
\text { (HCFMUSP), São Paulo, }\end{array}$ \\
& Brazil & \\
\end{tabular}

\begin{tabular}{lll}
\hline Yael Hacohen, & Queen Square MS Centre, & Designed and \\
MD, PhD & UCL Institute of Neurology, & conceptualized the study; \\
& Faculty of Brain Sciences, & analyzed data; and \\
University College London. & drafted the manuscript \\
& Department of Paediatric & for intellectual content \\
& Neurology, Great Ormond & \\
& Street Hospital for & \\
& Children, London, United & \\
& Kingdom & \\
\end{tabular}

\begin{tabular}{|c|c|c|}
\hline $\begin{array}{l}\text { Elise Yazbeck, } \\
\text { MD }\end{array}$ & $\begin{array}{l}\text { Assistance Publique- } \\
\text { Hôpitaux de Paris, } \\
\text { University Hospitals Paris } \\
\text { South, Bicêtre Hospital, Le } \\
\text { Kremlin Bicêtre, France }\end{array}$ & $\begin{array}{l}\text { Revised the manuscript } \\
\text { for intellectual content }\end{array}$ \\
\hline $\begin{array}{l}\text { Thais } \\
\text { Armangue, } \\
\text { MD, PhD }\end{array}$ & $\begin{array}{l}\text { Neuroimmunology } \\
\text { Program, Institut } \\
\text { d'Investigacions } \\
\text { Biomèdiques August Pi i } \\
\text { Sunyer (IDIBAPS), Hospital } \\
\text { Clínic, Universitat de } \\
\text { Barcelona, Barcelona, } \\
\text { Spain. Pediatric } \\
\text { Neuroimmunology Unit, } \\
\text { Sant Joan de Deu (SJD) } \\
\text { Children's Hospital, } \\
\text { Universitat de Barcelona, } \\
\text { Barcelona, Spain }\end{array}$ & $\begin{array}{l}\text { Revised the manuscript } \\
\text { for intellectual content }\end{array}$ \\
\hline $\begin{array}{l}\text { Arlette } \\
\text { Bruijstens, } \\
\text { MD }\end{array}$ & $\begin{array}{l}\text { Department of Neurology, } \\
\text { Erasmus University } \\
\text { Medical Center, } \\
\text { Rotterdam, the } \\
\text { Netherlands }\end{array}$ & $\begin{array}{l}\text { Revised the manuscript } \\
\text { for intellectual content }\end{array}$ \\
\hline
\end{tabular}


Appendix (continued)

\begin{tabular}{|c|c|c|}
\hline Name & Location & Contribution \\
\hline $\begin{array}{l}\text { Christian } \\
\text { Lechner, MD }\end{array}$ & $\begin{array}{l}\text { Division of Paediatric } \\
\text { Neurology, Department of } \\
\text { Pediatrics I, Medical } \\
\text { University of Innsbruck, } \\
\text { Innsbruck, Austria }\end{array}$ & $\begin{array}{l}\text { Revised the manuscript } \\
\text { for intellectual content }\end{array}$ \\
\hline $\begin{array}{l}\text { Samira Luisa } \\
\text { Apostolos- } \\
\text { Pereira, MD, } \\
\text { PhD }\end{array}$ & $\begin{array}{l}\text { Department of Neurology, } \\
\text { Hospital das Clínicas, } \\
\text { Faculty of Medicine, } \\
\text { University of São Paulo } \\
\text { (HCFMUSP), São Paulo, } \\
\text { Brazil }\end{array}$ & $\begin{array}{l}\text { Revised the manuscript } \\
\text { for intellectual content }\end{array}$ \\
\hline $\begin{array}{l}\text { Yana } \\
\text { Martynenko, } \\
\text { MD }\end{array}$ & $\begin{array}{l}\text { Medical Center of Physical } \\
\text { Therapy and Pain } \\
\text { Medicine INNOVO, Lviv, } \\
\text { Ukraine }\end{array}$ & $\begin{array}{l}\text { Revised the manuscript } \\
\text { for intellectual content }\end{array}$ \\
\hline $\begin{array}{l}\text { Markus Breu, } \\
\text { MD }\end{array}$ & $\begin{array}{l}\text { Division of Pediatric } \\
\text { Neurology, Department of } \\
\text { Pediatrics and Adolescent } \\
\text { Medicine, Medical } \\
\text { University of Vienna, } \\
\text { Vienna, Austria }\end{array}$ & $\begin{array}{l}\text { Revised the manuscript } \\
\text { for intellectual content }\end{array}$ \\
\hline
\end{tabular}

\begin{tabular}{lll}
\hline $\begin{array}{l}\text { Carolina de } \\
\text { Medeiros } \\
\text { Rimkus, MD, } \\
\text { PhD }\end{array}$ & $\begin{array}{l}\text { Department of Radiology } \\
\text { (INRAD), Hospital das }\end{array}$ & $\begin{array}{l}\text { Revised the manuscript } \\
\text { for intellectual content } \\
\text { Clínicas, Faculty of } \\
\text { Medicine, University of } \\
\text { São Paulo (HCFMUSP), São } \\
\text { Paulo, Brazil }\end{array}$ \\
\hline $\begin{array}{l}\text { Evangeline } \\
\text { Wassmer, MD }\end{array}$ & $\begin{array}{l}\text { Pediatric Neurology, } \\
\text { Birmingham Women and } \\
\text { Children's Hospital, } \\
\text { Birmingham, United } \\
\text { Kingdom }\end{array}$ & $\begin{array}{l}\text { Revised the manuscript } \\
\text { for intellectual content }\end{array}$ \\
&
\end{tabular}

\begin{tabular}{lll}
\hline Matthias & Division of Paediatric & Revised the manuscript \\
Baumann, MD & Neurology, Department of & for intellectual content \\
& Pediatrics I, Medical & \\
& University of Innsbruck, & \\
& Innsbruck, Austria &
\end{tabular}

\begin{tabular}{lll}
\hline Laura Papetti, & Department of & Revised the manuscript \\
PhD & Neuroscience, Pediatric & for intellectual content \\
& Multiple Sclerosis Center, & \\
& Bambino Gesù Children & \\
& Hospital, IRCCS, Rome, & \\
& Italy
\end{tabular}

\begin{tabular}{lll}
\hline $\begin{array}{l}\text { Marco } \\
\text { Capobianco, } \\
\text { MD }\end{array}$ & $\begin{array}{l}\text { Department of Neurology } \\
\text { and Regional Multiple } \\
\text { Sclerosis Centre, } \\
\text { University Hospital San } \\
\text { Luigi Gonzaga, Orbassano, } \\
\text { Italy }\end{array}$ & $\begin{array}{l}\text { Revised the manuscript } \\
\text { for intellectual content }\end{array}$ \\
\hline $\begin{array}{l}\text { Barbara } \\
\text { Kornek, MD, } \\
\text { PhD }\end{array}$ & $\begin{array}{l}\text { Department of Neurology, } \\
\text { Medical University of } \\
\text { Vienna, Vienna, Austria }\end{array}$ & $\begin{array}{l}\text { Revised the manuscript } \\
\text { for intellectual content }\end{array}$ \\
\hline $\begin{array}{l}\text { Kevin Rostásy, } \\
\text { MD }\end{array}$ & $\begin{array}{l}\text { Department of Pediatric } \\
\text { Neurology, Vestische }\end{array}$ & $\begin{array}{l}\text { Revised the manuscript } \\
\text { for intellectual content }\end{array}$ \\
& $\begin{array}{l}\text { Kinder und Jugendklinik, } \\
\text { Witten/Herdecke }\end{array}$ & \\
& $\begin{array}{l}\text { University, Datteln, } \\
\text { Germany }\end{array}$ & \\
\hline $\begin{array}{l}\text { José Albino da } \\
\text { Paz, MD, PhD }\end{array}$ & $\begin{array}{l}\text { Department of Neurology, } \\
\text { Hospital das Clínicas, Faculty } \\
\text { of Medicine, University of }\end{array}$ & $\begin{array}{l}\text { Revised the manuscript } \\
\text { for intellectual content }\end{array}$ \\
& $\begin{array}{l}\text { São Paulo (HCFMUSP), São } \\
\text { Paulo, Brazil }\end{array}$ & \\
\hline & & \\
\hline
\end{tabular}

Appendix (continued)

\begin{tabular}{|c|c|c|}
\hline Name & Location & Contribution \\
\hline $\begin{array}{l}\text { Olga } \\
\text { Ciccarelli, MD, } \\
\text { PhD }\end{array}$ & $\begin{array}{l}\text { Queen Square MS Centre, } \\
\text { UCL Institute of Neurology, } \\
\text { Faculty of Brain Sciences, } \\
\text { University College London, }\end{array}$ & $\begin{array}{l}\text { Interpreted the data and } \\
\text { revised the manuscript } \\
\text { for intellectual content }\end{array}$ \\
\hline
\end{tabular}

Ming Lim, MD, Children's Neurosciences, Interpreted the data and PhD Evelina London Children's revised the manuscript Hospital at Guy's and St for intellectual content Thomas' NHS Foundation Trust, King's Health Partners Academic Health Science Centre, London, United Kingdom; Faculty of Life Sciences and Medicine, King's College Hospital, London, United Kingdom

\begin{tabular}{lll}
\hline $\begin{array}{l}\text { Albert Saiz, } \\
\text { MD, PhD }\end{array}$ & $\begin{array}{l}\text { Neurology Service, } \\
\text { Hospital Clinic, and Institut } \\
\text { d'Investigacions } \\
\text { Biomèdiques August Pi i } \\
\text { Sunyer (IDIBAPS), } \\
\text { University of Barcelona, } \\
\text { Barcelona, Spain }\end{array}$ & $\begin{array}{l}\text { Revised the manuscript } \\
\text { for intellectual content }\end{array}$ \\
& & \\
\hline $\begin{array}{l}\text { Rinze } \\
\text { Neuteboom, } \\
\text { MD, PhD }\end{array}$ & $\begin{array}{l}\text { Department of Neurology, } \\
\text { Erasmus University }\end{array}$ & $\begin{array}{l}\text { Revised the manuscript } \\
\text { for intellectual content }\end{array}$ \\
& $\begin{array}{l}\text { Medical Center, } \\
\text { Rotterdam, the }\end{array}$ & \\
& Netherlands & \\
\hline
\end{tabular}

\begin{tabular}{lll}
\hline Romain & Neurology Department, & Interpreted the data and \\
Marignier, & Hôpital Neurologique & revised the manuscript \\
MD, PhD & Pierre Wertheimer, & for intellectual content
\end{tabular}

MD, PhD Pierre Wertheimer, for intellectual content Hospices Civils de Lyon, Lyon; French Reference Network of Rare Inflammatory Brain and Spinal Diseases, Le Kremlin Bicêtre, France

\begin{tabular}{|c|c|c|}
\hline $\begin{array}{l}\text { Cheryl } \\
\text { Hemingway, } \\
\text { MD, PhD }\end{array}$ & $\begin{array}{l}\text { Department of Paediatric } \\
\text { Neurology, Great Ormond } \\
\text { Street Hospital for } \\
\text { Children, London, United } \\
\text { Kingdom }\end{array}$ & $\begin{array}{l}\text { Interpreted the data and } \\
\text { revised the manuscript } \\
\text { for intellectual content }\end{array}$ \\
\hline $\begin{array}{l}\text { Douglas } \\
\text { Kazutoshi } \\
\text { Sato, MD, PhD }\end{array}$ & $\begin{array}{l}\text { School of Medicine, Brain } \\
\text { Institute of Rio Grande do } \\
\text { Sul (Brains), Pontifical } \\
\text { Catholic University of Rio } \\
\text { Grande Do Sul (PUCRS), } \\
\text { Porto Alegre, Brazil }\end{array}$ & $\begin{array}{l}\text { Interpreted the data and } \\
\text { drafted the manuscript } \\
\text { for intellectual content }\end{array}$ \\
\hline $\begin{array}{l}\text { Kumaran } \\
\text { Deiva, MD, } \\
\text { PhD }\end{array}$ & $\begin{array}{l}\text { Assistance Publique- } \\
\text { Hôpitaux de Paris, } \\
\text { University Hospitals Paris } \\
\text { South, Bicêtre Hospital, Le } \\
\text { Kremlin Bicêtre, France. } \\
\text { French Reference Network } \\
\text { of Rare Inflammatory } \\
\text { Brain and Spinal Diseases, } \\
\text { Le Kremlin Bicêtre, France. } \\
\text { Inserm UMR 1184, } \\
\text { Immunology of Viral } \\
\text { Infections and } \\
\text { Autoimmune Diseases, } \\
\text { CEA, IDMIT, Le Kremlin } \\
\text { Bicêtre, France }\end{array}$ & $\begin{array}{l}\text { Designed and } \\
\text { conceptualized the study; } \\
\text { analyzed data; and } \\
\text { drafted the manuscript } \\
\text { for intellectual content }\end{array}$ \\
\hline
\end{tabular}




\section{References}

1. Lennon VA, Wingerchuk DM, Kryzer TJ, et al. A serum autoantibody marker of neuromyelitis optica: distinction from multiple sclerosis. Lancet 2004;364:2106-2112.

2. Sato DK, Nakashima I, Takahashi T, et al. Aquaporin-4 antibody-positive cases beyond current diagnostic criteria for NMO spectrum disorders. Neurology 2013;80: 2210-2216.

3. Wingerchuk DM, Banwell B, Bennett JL, et al. International consensus diagnostic criteria for neuromyelitis optica spectrum disorders. Neurology 2015;85:177-189.

4. Rostasy K, Reindl M. Role of autoantibodies in acquired inflammatory demyelinating diseases of the central nervous system in children. Neuropediatrics 2013;44:297-301.

5. Tillema JM, McKeon A. The spectrum of neuromyelitis optica (NMO) in childhood. J Child Neurol 2012;27:1437-1447.

6. Mealy MA, Wingerchuk DM, Palace J, Greenberg BM, Levy M. Comparison of relapse and treatment failure rates among patients with neuromyelitis optica: multicenter study of treatment efficacy. JAMA Neurol 2014;71:324-330.

7. Palace J, Leite MI, Nairne A, Vincent A. Interferon beta treatment in neuromyelitis optica: increase in relapses and aquaporin 4 antibody titers. Arch Neurol 2010;67: 1016-1017.

8. Banwell B, Tenembaum S, Lennon VA, et al. Neuromyelitis optica-IgG in childhood inflammatory demyelinating CNS disorders. Neurology 2008;70:344-352.

9. Huppke P, Bluthner M, Bauer O, et al. Neuromyelitis optica and NMO-IgG in European pediatric patients. Neurology 2010;75:1740-1744.

10. McKeon A, Lennon VA, Lotze T, et al. CNS aquaporin-4 autoimmunity in children. Neurology 2008;71:93-100.

11. Chitnis T, Ness J, Krupp L, et al. Clinical features of neuromyelitis optica in children: US Network of Pediatric MS Centers report. Neurology 2016;86:245-252.

12. Banwell B, Bar-Or A, Arnold DL, et al. Clinical, environmental, and genetic determinants of multiple sclerosis in children with acute demyelination: a prospective national cohort study. Lancet Neurol 2011;10:436-445.

13. Hacohen Y, Absoud M, Woodhall M, et al. Autoantibody biomarkers in childhoodacquired demyelinating syndromes: results from a national surveillance cohort. J Neurol Neurosurg Psychiatry 2014;85:456-461.

14. Hacohen Y, Mankad K, Chong WK, et al. Diagnostic algorithm for relapsing acquired demyelinating syndromes in children. Neurology 2017;89:269-278.

15. Collongues N, Marignier R, Zephir H, et al. Long-term follow-up of neuromyelitis optica with a pediatric onset. Neurology 2010;75:1084-1088.

16. Kitley J, Leite MI, Nakashima I, et al. Prognostic factors and disease course in aquaporin-4 antibody-positive patients with neuromyelitis optica spectrum disorder from the United Kingdom and Japan. Brain 2012;135:1834-1849.

17. Krupp LB, Tardieu M, Amato MP, et al. International Pediatric Multiple Sclerosis Study Group criteria for pediatric multiple sclerosis and immune-mediated central nervous system demyelinating disorders: revisions to the 2007 definitions. Mult Scler 2013;19:1261-1267.

18. Marignier R, Bernard-Valnet R, Giraudon P. Aquaporin-4 antibody-negative neuromyelitis optica: distinct assay sensitivity-dependent entity. Neurology 2013;80:2194-2200.

19. Sato DK, Callegaro D, Lana- Peixoto MA, et al. Distinction between MOG antibodypositive and AQP4 antibody-positive NMO spectrum disorders. Neurology 2014;82: 474-481.
20. Waters PJ, Pittock SJ, Bennett JL, Jarius S, Weinshenker BG, Wingerchuk DM. Evaluation of aquaporin-4 antibody assays. Clin Exp Neuroimmunol 2014;5:290-303.

21. Höftberger R, Sepulveda M, Armangue T. Antibodies to MOG and AQP4 in adults with neuromyelitis optica and suspected limited forms of the disease. Mult Scler 2015 21:1086-1094.

22. van Pelt ED, Wong YY, Ketelslegers IA. Neuromyelitis optica spectrum disorders: comparison of clinical and magnetic resonance imaging characteristics of AQP4-IgG versus MOG-IgG seropositive cases in the Netherlands. Eur J Neurol 2015;23:580-587.

23. Ketelslegers IA, Modderman PW, Vennegoor A. Antibodies against aquaporin-4 in neuromyelitis optica: distinction between recurrent and monophasic patients. Mult Scler 2011;17:1527-1530.

24. Kim SH, Mealy MA, Levy M, et al. Racial differences in neuromyelitis optica spectrum disorder. Neurology 2018;91:e2089-e2099.

25. Dale RC, Brilot F, Duffy LV, et al. Utility and safety of rituximab in pediatric autoimmune and inflammatory CNS disease. Neurology 2014;83:142-150.

26. Nosadini M, Alper G, Riney CJ, et al. Rituximab monitoring and redosing in pediatric neuromyelitis optica spectrum disorder. Neurol Neuroimmunol Neuroinflamm 2016; 3:e188.

27. Marcinno A, Marnetto F, Valentino P, et al. Rituximab-induced hypogammaglobulinemia in patients with neuromyelitis optica spectrum disorders. Neuro Neuroimmunol Neuroinflamm 2018;5:e498.

28. Costanzi C, Matiello M, Lucchinetti CF, et al. Azathioprine: tolerability, efficacy, and predictors of benefit in neuromyelitis optica. Neurology 2011;77:659-666.

29. Huh SY, Kim SH, Hyun JW, et al. Mycophenolate mofetil in the treatment of neuromyelitis optica spectrum disorder. JAMA Neurol 2014;71:1372-1378.

30. Kim SH, Jeong IH, Hyun JW, et al. Treatment outcomes with rituximab in 100 patients with neuromyelitis optica: influence of FCGR3A polymorphisms on the therapeutic response to rituximab. JAMA Neurol 2015;72:989-995.

31. Gorman MP, Healy BC, Polgar-Turcsanyi M, Chitnis T. Increased relapse rate in pediatric-onset compared with adult-onset multiple sclerosis. Arch Neurol 2009;66: 54-59.

32. Hacohen Y, Wong YY, Lechner C, et al. Disease course and treatment responses in children with relapsing myelin oligodendrocyte glycoprotein antibody-associated disease. JAMA Neurol 2018;75:478-487.

33. Kleiter I, Gahlen A, Borisow N, et al. Neuromyelitis optica: evaluation of 871 attacks and 1,153 treatment courses. Ann Neurol 2016;79:206-216.

34. Kleiter I, Gahlen A, Borisow N, et al. Apheresis therapies for NMOSD attacks: a retrospective study of 207 therapeutic interventions. Neurol Neuroimmunol Neuroinflamm 2018;5:e504.

35. Bonnan M, Valentino R, Debeugny S, et al. Short delay to initiate plasma exchange is the strongest predictor of outcome in severe attacks of NMO spectrum disorders. J Neurol Neurosurg Psychiatry 2018;89:346-351.

36. Yamamura T, Kleiter I, Fujihara K, et al. Trial of satralizumab in neuromyelitis optica spectrum disorder. N Engl J Med 2019;381:2114-2124.

37. Cree BAC, Bennett JL, Kim HJ, et al. Inebilizumab for the treatment of neuromyelitis optica spectrum disorder (N-MOmentum): a double-blind, randomised placebocontrolled phase 2/3 trial. Lancet 2019;394:1352-1363.

38. Pittock SJ, Berthele A, Fujihara K, et al. Eculizumab in aquaporin-4-positive neuromyelitis optica spectrum disorder. N Engl J Med 2019;381:614-625. 


\section{Neurology \\ Neuroimmunology \& Neuroinflammation}

Treatment and outcome of aquaporin-4 antibody-positive NMOSD: A multinational pediatric study

Renata Barbosa Paolilo, Yael Hacohen, Elise Yazbeck, et al.

Neurol Neuroimmunol Neuroinflamm 2020;7;

DOI 10.1212/NXI.0000000000000837

This information is current as of July 30, 2020

Neurol Neuroimmunol Neuroinflamm is an official journal of the American Academy of Neurology.

Published since April 2014, it is an open-access, online-only, continuous publication journal. Copyright

Copyright $\left({ }^{\circ} 2020\right.$ The Author(s). Published by Wolters Kluwer Health, Inc. on behalf of the American

Academy of Neurology.. All rights reserved. Online ISSN: 2332-7812.

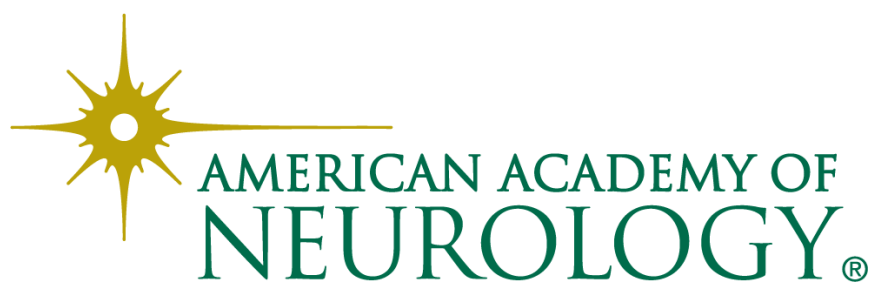




\section{Updated Information \& Services}

References

Citations

Subspecialty Collections

Permissions \& Licensing

Reprints including high resolution figures, can be found at: http://nn.neurology.org/content/7/5/e837.full.html

This article cites 38 articles, 5 of which you can access for free at: http://nn.neurology.org/content/7/5/e837.full.html\#\#ref-list-1

This article has been cited by 4 HighWire-hosted articles: http://nn.neurology.org/content/7/5/e837.full.html\#\#otherarticles

This article, along with others on similar topics, appears in the following collection(s):

Autoimmune diseases

http://nn.neurology.org//cgi/collection/autoimmune_diseases Devic's syndrome

http://nn.neurology.org//cgi/collection/devics_syndrome

Optic neuritis; see Neuro-ophthalmology/Optic Nerve http://nn.neurology.org//cgi/collection/optic_neuritis

Transverse myelitis

http://nn.neurology.org//cgi/collection/transverse_myelitis

Information about reproducing this article in parts (figures,tables) or in its entirety can be found online at:

http://nn.neurology.org/misc/about.xhtml\#permissions

Information about ordering reprints can be found online: http://nn.neurology.org/misc/addir.xhtml\#reprintsus

Neurol Neuroimmunol Neuroinflamm is an official journal of the American Academy of Neurology.

Published since April 2014, it is an open-access, online-only, continuous publication journal. Copyright

Copyright $\odot 2020$ The Author(s). Published by Wolters Kluwer Health, Inc. on behalf of the American

Academy of Neurology.. All rights reserved. Online ISSN: 2332-7812.

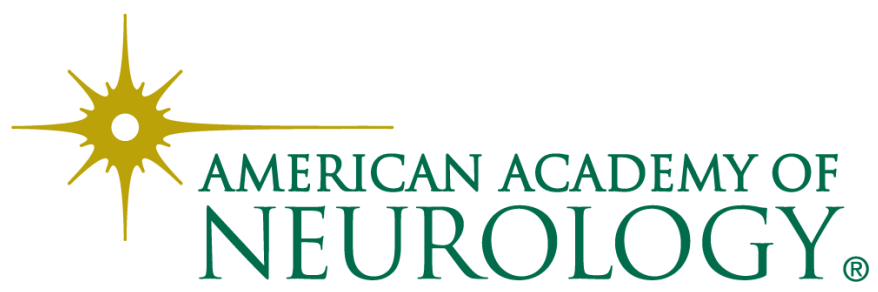

